\title{
Creative Education, A Tool for Changing the Narrative of the Chew and Pour System of Education, Prerequisite for Promoting Entrepreneurship and Modern Day Business Management
}

\author{
Dr. Ernest Amankwah \\ Freelance Researcher \\ Office of Head of Local Government Service, (Ohlgs) \\ motigov5@yahoo.com
}

\begin{abstract}
:
The traditional educational system has ended up producing mostly products of pen pushers (Prof. Nsowah Nuamah, 2005). The modern educational system must not only be directed towards the development of the arms of future specialists by professional knowledge and abilities, but also on formation of free creative thinkers, requirement to continuous self-education needful for the required innovation in the business world. This research work is devoted to one of actual problems in education to a problem of search of innovative approaches in formation of creative thinking of students. The literary review containing disclosure of the concepts "creativity" by different educational scientists among which are Sir Kenneth Robinson, an English citizen (November 2014), Clara Hemphill, a Pulitzer Prize-winning journalist and Randi Weingarten etc all give credence to the subject matter under review. In a generalized view, creativity discussed as ability to put forward original, non-standard ideas, to apply various strategy in the solution of problems, readiness to develop the arisen ideas. "Creativity" is understood by many researchers as deviation from the status quo way of approach. The "chew and pour" system of education has produced what is termed as graduates of mass destruction in the industrial world. It follows from this that process of formation and development of creative thinking of students demands serious training from outside of both the teacher, and students as it is connected with selection of sources, generalization and systematization of the available knowledge and experience, definition of receptions and methods of realization of projects tasks. (Ibragimova Gulsanam Nematovna, 2015). Whilst the business world operates on the tenets of conscious capitalism (Dr. Amber Gove is Director of Research within RTI's International Education Division) the educational system must ensure to retool the thinking capacities of students. The problem of development of creative identity of trainees is modern and significant. Education must be seen as a holistic venture to produce outside the box thinkers who will not only be seen as conformists but will aspire to challenge the status quo.
\end{abstract}

Key words: Cognitive activity; Self-education; skills of research; professional knowledge; Strategy 